\title{
Educational Expenditure and Economic Welfare in Sub Saharan African Countries: Effects and Transmission Channels
}

\author{
Felix Dabit Atabukum ${ }^{\mathrm{a}}$, Daniel Akume ${ }^{\mathrm{b}}$, Urie Eléazar Jumbo ${ }^{\mathrm{a}, \mathrm{c}}$ \\ ${ }^{a}$ Faculty of Economics and Management Sciences, The University of Bamenda, Cameroon \\ ${ }^{b}$ Higher Technical Teachers' Training College, University of Buea, Cameroon \\ ${ }^{c}$ Faculty of Economics and Management, University of Dschang, Cameroon
}

\begin{abstract}
This study sets out to evaluate how public educational expenditure affects economic welfare. Specifically, we investigated the effects and the transmission channels of public educational expenditure on economic welfare in 15 Sub Saharan African (SSA) countries from 2000-2017. We sourced data from the World Development Indicators, World Governing Indicators, the Freedom House and Polity IV data bases. We used the Panel Corrected Standard Errors Estimator (PCSE) in a static model framework to evaluate the direct effects of educational expenditure on economic welfare and the causal mediation analysis to assess the channels through which public educational expenditures affect economic welfare. Our results from the PCSE estimator revealed that the square of public educational expenditure, democracy, access to education, quality governance, trade openness and financial development positively and significantly affect economic welfare in SSA countries while educational expenditure has negative and significant direct effects. However, based on the causal mediation analysis, we found out that trade openness, governance, democracy and educational access positively and significantly mediated the negative effects of public educational expenditure on economic welfare in SSA. On the basis, we strongly recommend that governments should increase the sizes of public spending on education, improve on governance, improve on access to education and liberalise their economies.
\end{abstract}

Key words: Economic welfare; Education; Expenditure

\section{Introduction}

Education has been described as a fundamental determinant of economic progress via human capital development, technological progress and innovations. Given this fundamental role, countries all over the world heavily finance education. For example, a study by Szirmai (2015) revealed that public spending in the educational sector in both middle and low income countries has been persistently high from 1965 up to date. Base on this study, public spending on education in high income countries on average in 1965 stood at $5.2 \%$ of the GDP. It rose to 5.6\% in 1970 and remained persistently high at 5.1\%, 5.0\%, 4.96\% and 5.62\% in 1980, 1990, 2000 and 2010 upwards. Information from World Bank (2018) also points to the fact that most developed regions in the world spend more on education that least developed regions. To cite, in 1999, 2000, 2010 and 2014, Euro area which harbors most of the most advanced nations in the world spent 4.8\%; $4.89 \%, 5.54 \%$ and $5.28 \%$ of their GDP on education respectively. This is against lower but rising spending of $3.13 \%, 2.89 \%$ and $3.54 \%$ in the least developed countries within the same period.

Human capital acquired via schooling is an endogenous cause of economic growth. It is theoretically a cause of persistent divergence in living standards between developed and developing countries. Evidence from literature reveals that the most industrialised nations in the world today invested heavily especially on primary education in the $19^{\text {th }}$ century. Given that educational investment is long term investment, such expenditure accounted for their rapid growth rate even 20 years after. A study by Tanzi and Schuktnecht (2000) provides supporting evidence to this. According to this piece of work, in 1870 developed countries like Norway, France, United Kingdom(UK), Germany and Spain spent $0.50 \%, 0.3 \%, 0.10 \%$ and $1.3 \%$ of their GDP respectively on education. In 1913, the proportions of their GDP invested on education rose to $1.4 \%, 1.5 \%, 1.1 \%, 2.7 \%$ and $0.4 \%$ respectively. In 1937 the same countries persistently spent $1.9 \%, 1.3 \%, 4 \%$ and $1.6 \%$ of their GDP on education. By 1980 public funding of education in this group of countries rose to $7.2 \%, 5 \%, 5.6 \%, 4.7 \%$ and $2.6 \%$ of their GDP respectively. In 1993 all these countries spent as high as $9.6 \%, 5.9 \%, 5.7 \%, 4.8$ and $4.7 \%$ of their national incomes on education respectively. Such high levels of spending on education in 1993 were capable to propel economic growth up to 2013 in these countries.

Despite this empirical evidence, there are numerous theoretical and other empirical contradictions on the effects of educational spending on economic welfare. To begin with the Keynesians (Keynes, 1936) consider 
public spending as instrument that government can use to boost the growth of the economy in the short run via the multiplier process. To this class of economists, public spending in the real sector can crowd in private investment and as such increases economic growth. This opinion has been challenged by Wagner Law (Ibok and Bassey, 2014). To Wagner (Wagner, 1883), it is rather the growth of the economy that provokes the growth of public expenditures. On this ground, public educational expenditures should rather response to the growth of per capita income. This is at variant with the Keynesian view which opines that the growth of the public spending causes the growth of per capita income. The classical are even of the opinion that government intrusion in the economy can be detrimental to economic growth because of the crowding out and market distortions effects (Jambo, 2017). In theory, increasing public spending is not a guarantee for improved welfare. The Ricardian equivalent hypothesis is in support of this (Barro, 1989). According to this hypothesis, under rational hypothesis, an increase in public spending from debt financing at the moment would mean that government will raise taxes in the future to pay back her debts. On this basis, households will rather increase their savings to back up the future fall in their disposable income and as such their current consumption remains unchanged (Siddiki, 2010).

Barro (1991) also opined that productive public spending like educational spending boosts economic growth while unproductive spending retards growth. As part of this controversies Mitchell (2005) based on the ARMEY or Rahn curve hypothesis opined that "when the economy grows too large, the economy shrinks". This puts to question the very linear link between public expenditure and economic growth there by making it an inverted U shape (Barro, 1989; Armey, 1995; Rahn and Fox, 1996? Scully, 1994 and 2008).

The theoretical contradictions notwithstanding, endogenous growth theories predict that education enhances human capital which goes to improve productivity and consequently better economic welfare. To Becker (1966) and Mincer (1974), education improves on the productivity of workers which increases their earnings. Romer (1986 and 1990) holds that knowledge or ideas are the determinants of a country long term growth in per capita income while that Research and Development spending (R and D) enhances economic growth respectively. This view is also upheld by Lucas (1988) in his human capital model. To corroborate this, Rebelo (1991) in the AK model also revealed that human capital explains permanent growth in per capita income across countries. This is corroborated by the theoretical and empirical studies of Mankiw et al. (1992).

Recent studies on the effects of education on economic growth or welfare are centered on the quality of education. Hanushek and Woessmann (2007 and 2012) are of the opinion that it is the quality of education captured by cognitive skills that are more robust to economic growth than the quantity of education (Lucas, 1988,Romer 1986 and Mankiw et al (1992). In this new line of studies, the issue of quality institutions has also been evoked. Accordingly, the effects of public spending on educational outcomes depends on the quality of institutions or good governance (Kimaro, 2017, Hanushek and Woessmann (2007), Trabelsi (2017 and 2018 , Kagundu, 2006, Rajkumar and Swaroop, 2007).

Given the robust effects of human capital on economic growth, countries with low human capital bases like those in SSA are admonished to invest heavily on education so as to raise their levels of human capital and consequently their macro performances. The United Nations Educational, Scientific and Cultural Organisation (UNESCO (2011)) admonished that these countries should spend between 4\%-6\% of their GNP on education or between $15 \%-20 \%$ of their total budgets on education. Report by African Development Bank (AfDB: 2020) reveals that more than $50 \%$ of these countries are within the UNESCO target but the long term outcome which is economic growth continue to be dismal across the board. The following statistics elucidate this point. SSA countries spent $16.9 \%$ and $3.84 \%$ of the public budget and GDP on the educational sector on average respectively from 2010-2018 (World Bank, 2020). From 1980 to 2018, except for the year 2008 when the share of educational spending in total public budget fell to about $13.5 \%$, the public spending rate has always been above $14 \%$. Although gross primary enrolment rate improved to $97.8 \%$ in 2018 , the adjusted net primary enrolment rate (ANER) is still below $70 \%$ while the secondary and tertiary enrolment rates in 2018 were mere $43.40 \%$ and $9.4 \%$ respectively.

The situation is even more appalling when one considers the ultimate goal of public educational spending which is the economic growth rate. The economic growth rate per annum in SSA has been volatile and inconsistent. In 1979 when the public educational spending was $15.5 \%$ of total public spending, the growth rate was just about $1.16 \%$. Despite the consistency in the growth of the absolute and relative amounts of spending, the growth rate of GDP per year at maximum has been only 4\% from 1979 to 2020 . Very disappointing and even negative growth rates were recorded from 1981-1987; 1991-1994 and 1998 (World Bank, 2020). Recently the public educational spending rate has jumped to about $17 \%$ of total public spending but the economic growth rate in 2016,2017 and 2018 were $-1.4 \%,-0.1669 \%$ and -0.29 respectively. There is no uniformity in spending pattern across countries in SSA. While some countries like; Djibouti, Botswana, Namibia, Lesotho, South Africa, Zimbabwe and Cape Verde spent more than between 5\% and 8.5\% percent of their GDP on education from 2015 -2018, others displayed very lower educational spending within the same period. For example, Zambia, Democratic Republic of Congo, Equatorial Guinea, South Sudan spent less than $2 \%$ percent of their GDP on education. 
Economic theory predicts that more investment in education should impact on educational on human capital, health and growth positively. Statistical evidence points otherwise in SSA. This dismal performance in SSA is attributed to market distortions, breaks in employment, brain drain, government failures, under employment. Dhruv (2020) reports that SSA spend more on education but have the worse efficiency levels relative to the rest of the world. This report reveal that the efficiency level of public educational spending in 2018 in these countries was just about $58 \%$ for primary education and $41 \%$ in secondary education. This appealing information has also corroborated by the findings of Fonchamnyo and Sama (2014) in Central Africa and Koku (2015) in West Africa. This efficiency is very low when compared with efficiency levels of more than $80 \%$ in the European union, Asia and LAC at primary education and 80\%, 72\%, 76\% and 78\% efficiency levels of public educational spending recorded in European Union, Asia, Latin America and the Caribbean (LAC) as well as Emerging European countries. On the basis of the above contradictions, this study intends to investigate how public educational expenditure affects economic welfare in SSA countries. More specifically, the specific objectives of this study are to:

- Assess the direct effects of increasing public educational expenditure on economic welfare in SSA countries.

- Evaluate the extent to which trade openness, democracy, educational access, governance quality and technological progress mediate the effects of public educational expenditure on economic welfare in SSA countries.

- Make policy recommendations that can help improve on the effectiveness of public educational expenditure on the economic conditions of the people in SSA countries.

The relevance of our theme is in three folds. First we make our quota to the ongoing debate as to whether money matters for educational outcomes. Secondly, we bring out the roles of quality institutions on improving the effectiveness of educational spending especially in countries with limited financial resources. Lastly, since economic welfare determines social welfare, investigating the determinants of economic welfare helps to identify policies that can be used to ameliorate social welfare.

From this juncture, the rest o the paper is structured as follows: Section 2 briefly reviews the literature. Section 3 describes the empirical methodology. Section 4 presents and discusses results and section 5 makes the conclusion and recommendations.

\section{Literature Review and Hypotheses}

\subsection{Effects of Public Educational Spending on Economic Welfare: An Evaluation of Direct Effects}

\subsubsection{Positive Effects of Public Educational Expenditures}

Public educational spending has yielded inconsistent and inconclusive results in empirical studies. To justify this, we lay proof on a Meta analysis which was carried on 29 empirical studies by Fabrizio (2016). This Meta study revealed that out of 29 reviews, only 14 depicted positive effects of public educational spending on welfare, 12 revealed negative effects and 3 showed no significant effects of public spending on welfare. To begin with studies in Africa, Mussagy and Babatunde (2015) examined the effect of government education expenditure and economic growth in Mozambique using a co-integration approach and quarterly data between 1996 and 2012. Their co-integration and error-correction analysis confirmed that a long run relationship exists between economic growth and government expenditure in Mozambique. Touruam et al, (2014) investigated effects of government spending in tertiary education on per capita income in Nigeria from 1990 to 2011. The findings indicated that government spending on education had significant effects positive on economic growth. The study of Babalola and Aminu (2011) also points to a long run positive relationship between educational spending and economic growth. To Urhie (2014), the effects of public educational expenditures on growth depend on its composition. Based on Nigeria, the author studied the link between disaggregated public educational into current and capital educational expenditures and economic growth. He used the 2SLS approach. His results revealed that public educational expenditures had positive direct effects on economic growth. However, when the author disaggregated educational expenditures into capital and recurrent expenditures, the effects became different. While capital expenditures had positive effects on human capital, the effects on economic growth were negative but current expenditures had positive and negative effects on economic growth and human capital respectively (Oluwatobi, and Ogunrinola, 2011). The negative as well as non significant effects of capital educational expenditures on growth can be traced from the crowding out effects, poor role of institutions or governance, poor nature of country tax system and source of finance (Riedl, 2008; Cakerri et al. 2014; Gisore et al. 2015). Other related empirical studies in SSA which depict positive effects of educational spending on economic welfare include the studies of Eggoh et al, (2015), Fonkeng and Ntembe (2009), Musila and Belassi (2004). These are corroborated by the study of Ndoye (2013). A number of other studies like that of Maitra and Mukhopadhyay (2012), Neycheva (2010), Brempong (2010); Appiah et al (2017), Kohl (2015) which are out of Africa also reveal positive effects of public educational expenditure on welfare. 


\subsubsection{Negative and No Effects of Public Educational Expenditure on Economic Welfare}

Public expenditure is not necessarily a panacea to poor economic welfare. Devarajan et al. (1996) had earlier concluded that educational spending has a negative effect on economic growth in some developing countries because most of these countries allocate less budget to capital expenditures. The result is consistent with the findings of Diyoke and Demirbas (2018) based on lower and middle income countries in SSA. Equally, this result is corroborated by that of Bexheti and Mustafi (2015) in Macedonia and Trabelsi (2017). The study of Deskins et al. (2019) in USA also revealed that public spending on higher education has negative effects on state employment and gross state national product while Maitra and Mukhopadhyay (2012) concluded on a negative effect Nepal. Churchill et al. (2016) in their own study came to the conclusion that public educational spending has no effect on economic welfare in developing countries except in developed countries but Neil (2018) held that it has no effect on growth OECD countries but negative in developing countries. Kouton (2018) came to the same conclusion in Ivory Coast while Ndoye (2013) revealed similar result in Nigeria. In the same vien, Oluwatobi and Ogunrinola, (2011) concluded that capital educational spending has negative effects on economic growth in Nigeria. Blankneau and Simpson (2004) found no clear evidence on the link between public spending on education and economic growth. The study of Ditimi et al. (2011) in Nigeria supports the lack of relationship. On these bases, we post the first hypothesis as:

Hypothesis 1: An increase in public educational expenditure directly and significantly reduces economic welfare in SSA countries.

\subsubsection{The Indirect Effects of Public Educational Spending on Economic Welfare: An Evaluation of Channels}

If educational expenditure can impact on educational outcomes and educational outcomes affect well being, it means that education indirectly impact on well being. It can affect welfare indirectly via human capital enhancement or educational attainment or enrolment (Urhie, 2014 and Lestari, 2017). This is the Lucas (1988) channel according to which educational impacts on economic growth by first ameliorating human capital and hence productivity (Urhie, 2014, Romer, 1986, Romer, 1990a) which then ameliorates the productivity or efficiency of labour inputs. Following Hanushek and Woessman (2007), educational funding can affect economic growth via the quality of education and quality institutions like trade openness and property rights protections that promote innovations via incentives.

Education contributes to development also via non- human capital channels like: quality governance (control of corruption, voice and accountability, legal systems and property rights and democracy) and equality by empowering women the other vulnerable groups (Kagundu, 2006). Muhammad et al. (2016) held that institutions moderate the effects of public educational policy on welfare (poverty and inequality). This view are upheld by Kagundu (2006), Rajkumar and Swaroop (2007) who are of the opinion that the effects of public spending on economic outcomes depend on quality institutions or governance (Trabelsi, 2017and 2018 and Mohamed et al.2015, Butkielwicz and Yanikkaya, 2011).

To sum up a number of channels have been identified from education to economic welfare or growth. It can be via the interactive effects between human capital and labour productivity (Bils and Klenow, 2000; Hanushek and Kimko, 2000; Oketch, 2006; Temple, 2001). It can be via labour market participation (Glewwe, 2002, Klasen, 2002) and the interaction between human capital, foreign direct investment and domestic investment (Engelbrecht, 2003, Oketch, 2006) as well as the income effects of human capital which leads to creative destruction and the emergence of product varieties. It is also possible via the melting of cultural barriers and reduction in crimes by reducing the outlier population size. Essay (2018) points out that education affects welfare directly via empowerment and indirectly via mother schooling which improves child health and income earning capacity, family planning which limits child bearing, improves their schooling and improve household consumption as well as quick adoption of new technology.

Hypothesis 2: The effects of educational expenditure on economic welfare in SSA operate through technological progress, educational access, trade openness, governance quality and democracy.

Our study makes a contribution on the relationship between educational expenditure and economic welfare in SSA. Despite growing attention on the topic, existing studies do not investigate the channels via which educational expenditures affect economic welfare in SSA. Moreover, most studies on this topic examine the effects of education on economic growth as a measure of welfare. This measure is considered as a crude measure of welfare (Kuznet, 1934; Bafalina, 2018; Offer, 2000, Nordhaus and Tobin, 1972 and Van de Ven, 2018). So we contribute to literature by way of building an economic welfare indicator. Lastly, although there are many studies that examine the effects of educational expenditure on welfare, none has examined the important channels through which educational expenditure affect welfare in SSA. We take advantage of these lapses to create a composite index of economic welfare and evaluate the direct and channels of effects of educational expenditures on economic welfare. 


\section{Methodology}

Our econometric strategy on this aspect is in 2 stages. Firstly, we estimate the direct effects of educational expenditure on economic welfare while controlling for the effects of the transmission channels. Secondly, we use causal mediation analysis under the simultaneous equation framework to bring out the vital and significance of the pathways or channels via which public educational spending has effects on economic welfare. This follows the empirical strategy used by Avom et al.(2020), Kagundu (2006), Pellegrini and Gerlagh (2004).

\subsection{Basic Regression on the Effects of Public Educational Expenditure on Economic Welfare:}

Many methods have been developed to analyse the effects of public spending on economic growth. Kimaro (2017) used the modified Barro (1990) model while Urhie (2014) used the Barro \& Sala-i-Martin (2004) framework. In this paper, we adopt the modified version of the Ram (1986) and Grossman (1988) model. To do this, let us assume the aggregate production function of the form:

$$
Y=f(K, L)
$$

Where, Y: is output which is our welfare measure; K: physical capital, L: Labour, f: is a function of. Following Grossman (1988) and Ram (1986), government expenditure can be introduced into the equation as an independent variable. Assuming this case, the production function can be re-stated as:

$Y=f(K, L, G)$

Where $\mathrm{G}=$ Public educational spending. Considering a Cobb-Douglas production functional form, we obtain:

$Y=K^{a 1} L^{a 2} G^{a 3}$

Where $a_{1}, a_{2}$ and $a_{3}$ are the elasticities of physical capital, labour and public educational spending respectively. To obtain the marginal products of the equation above, we take total differentiation or derivative with respect to output or welfare as below.

$\frac{\partial Y}{\partial K}=\left(\frac{\partial Y}{\partial K}\right) \frac{\partial K}{Y}+\left(\frac{\partial Y}{\partial L}\right) \frac{\partial L}{Y}+\left(\frac{\partial L}{\partial G}\right) \frac{\partial G}{Y}$

From the model (4), we can now introduce other covariates which are often included in the economic welfare. Following the work of Urhie (2014), we can write the basic econometric model as follows:

$e w_{i t}=\beta o+\beta_{1} p e e g d p_{i t}+\beta j \sum_{2}^{6} C i t+\beta_{7}$ findev $_{i t}+n_{t}+v_{i}+\epsilon_{i t}$

Where $\mathrm{ew}_{\mathrm{it}}$ is the economic welfare indicator of country $i$ at the time $t$. This indicator is built on the basis of the first principal components of 5 sub indicators of economic welfare namely: wealth captured by domestic savings as a proportion of GDP, household final consumption of goods and services as a percentage of GDP, income or wealth inequality captured by the gini inequality index, employment captured by the labour force participation rate and environmentally sustainability captured by total global house gas emission in tons (Van de Ven, 2018; Pigou, 1932; Nordhaus and Tobin,1972; Daly and Cobb, 1994, Stiglitz et al. 2010 Balafina, 2018, Jumbo and Atabukum, 2020).

$\mathrm{C}_{\mathrm{it}}$ are other determinants of welfare which are the various channels via which educational spending affects economic welfare (Kagundu, 2006). These variables are carefully selected on the basis of theory and other empirical studies (Hanushek and Weossmann (2007), Solow (1956) Urhie (2014) and Uzawa (1965). Technical change which is our measure of educational quality and captures knowledge (Barro, 1986) or ideas (Barro, 1990a), educational access which captures human capita (Lucas, 1988) or quantity education (Hanushek and Woessmann, 2008 and Lucas, 1988, Rebelo, 1991). We include institutional factors like trade openness, governance and democracy as additional channels. findev is a measure of financial deepening or development (measures of depth) commonly used in growth literature and comprises of domestic credit to the private sector as a percentage of the GDP and broad money supply $\left(\mathrm{m}_{2}\right)$ as a percentage of the GDP. $\mathrm{B}_{\mathrm{j}}$ and $\beta_{7}$ are the parameters to be estimated while $\beta 0, v_{i}, n_{t}$ and $\epsilon_{i t}$ are the country intercept, the unobserved individual effects; time specific effect and the error terms respectively.

We further assume that the relationship between economic welfare (ew) and public expenditure can be non linear (Apiah, 2017). Following Rahn (Mitchell, 2005) excess public spending may deteriorate well being or growth under conditions of poor governance. There is also a strong argument as to whether excess spending or 
money matters for educational outcomes (Coleman et al. 1966, Hanushek and Woessman, 2007). On this basis, we conceive a non linear econometric model where in we square public educational spending. This will allow us to verify if excess spending on education matters for economic welfare. In this model, we re-write equation 5 but we now include all the regressors. This model is stated as:

$\mathrm{ew}_{\mathrm{it}}=\beta_{0}+\beta_{1}$ peegdpit $+\beta_{2}$ peegdp ${ }_{i t}^{2}+\beta_{3} \Omega_{\mathrm{it}}+\beta_{4} \operatorname{acindex}_{\mathrm{it}}+\beta_{50 p e n_{i t}}+\beta_{6} \mathrm{gov}_{\mathrm{it}}+\beta_{7}$ demo $_{i t}+\beta_{8}$

findevit $+n_{t}+v_{i}+\epsilon_{i t}$

$\Omega$ (Omega) is the technical change or progress. It captures technology progress or the Solow residual therefore the efficiency the school system (Uzawa, 1965). It is obtained from the estimation of the Solow model (Solow, 1956). acindex is the educational access index of country $i$ at the time $t$ captured by the gross enrolment rates at different levels of education, open is trade openness, governance is a measure of economic governance captured by control of corruption and government effectiveness and demo is the level of democracy. The rest of the variables remain as earlier defined. $\beta_{1}$ is expected to be $<0$ at apriori and $\beta_{2}$ to $\beta_{7}$ are expected to be positive.

\subsection{Exploring the Possible Channels from Public Educational Expenditure to Economic Welfare}

In order to test the second hypothesis, where educational access, trade openness, technical change, governance and democracy mediate the effects of public educational spending on economic welfare, we use causal mediation analysis (Avom et al. 2020). This method helps us to comprehend if and to what extent the effect of public educational spending on economic welfare is ameliorated through the mediators or channels. We assume that the implementation of public spending on education takes place prior to the channels (access or involvement, technical change, governance, democracy and trade openness)(Hanushek and Woessman, 2007). This is based on the idea that if educational expenditure affects educational outcomes and educational outcomes impact economic welfare, then indirectly, educational expenditure impacts on economic welfare (Fabrizio, 2018). In mediation analyses, we assume that educational expenditure first impact on the channels which via their interaction improve on the effects of public educational spending on economic welfare.

Our analysis follows the methodology used by Avom et al (2020) who investigated the effect ICT on environmental quality in SSA based on channels like trade openness, energy use and financial development. The mediation analysis is conceived by adopting and estimating the following model:

$Z_{i t}^{j}=\beta_{0}+\alpha_{1}$ peegdpit $+\epsilon_{i t}$

Where $Z_{i t}^{j}$ is the $j^{\text {th }}$ channel (school access or enrolment rate, trade openness, governance technical, change and democracy). $\boldsymbol{\alpha}_{\mathbf{1}}$ is the effect of public education spending on the transmission channel. The other signs and symbols remain as earlier defined. We estimate the above model using the simultaneous equation method to determine the effects of educational spending on each of the transmission channels. If $\boldsymbol{\alpha}_{\mathbf{1}}$ is statistically significant, it means educational spending explain part of the variation in the transmission channel. We then compute the indirect effect of public educational expenditure on economic welfare. To obtain the total effects (sum of direct and indirect effects), we substitute the above equation 7 in equation 5 and take the derivative of ew (economic welfare) with respect to peegdp (public educational spending) to obtain the following:

$(\text { ew })_{\mathrm{i} t} / \partial$ peegdpit $=\beta_{1}\left(\beta_{2} \times \alpha_{1}\right)+\left(\beta_{3} \times \mathrm{j}_{1}+\beta_{4} \times \partial_{1}+\beta_{5} \times \gamma_{1}+\beta_{6} \times \varphi_{1}+\beta_{7} \times \theta_{1}\right)$

The first term on the RHS of the equation, $\beta_{1}$ is the direct welfare effect of public educational spending and the indirect effects of public educational expenditures are given by the other terms in bracket.

\subsection{Techniques of Estimation and Sources of Data}

We use several panel regression techniques to estimate the above model. More specifically, we use the pooled OLS, FE and RE regression techniques. A number of diagnostic tests are done to choose the most appropriate model. To this end, we applied the Hausmann test (Baltagi, 2004) to select the most appropriate model. We also applied the Wald test (Stock and Watson, 2008) and Woodridge test (Woodridge, 2002) to check the group use heteroskedasticity and autocorrelation respectively (Dougherty, 2016). On the basis of the results; we adopted the PCSE and FGLS to estimate the parameters of the static model (Keufack et al, 2020) and causal mediation analysis under SEM framework to estimate the indirect and total effects of public educational expenditures on economic welfare.

They data are obtained from different sources such as: The World Development Indicators of the World Bank (WDI, 2018), Regional Strategic Alliance and Knowledge Sharing System (ReSAKSS, 2018) 2018), Economic Freedom Index of the Freedom House and Wall Street Journal (2018) and the World Governing Indicators of the World Bank (2018) 


\section{Presentation of Results and Discussions \\ 4.1. Pre-Assessment Tests \\ 4.1.1. Descriptive Statistics}

In this part of the work, we present a summary of the descriptive statistics. Figures 4.1 and 4.2 present a visual look of the main variables used. Figure 4.1 shows the evolution of the public educational spending and economic welfare index in sample countries.

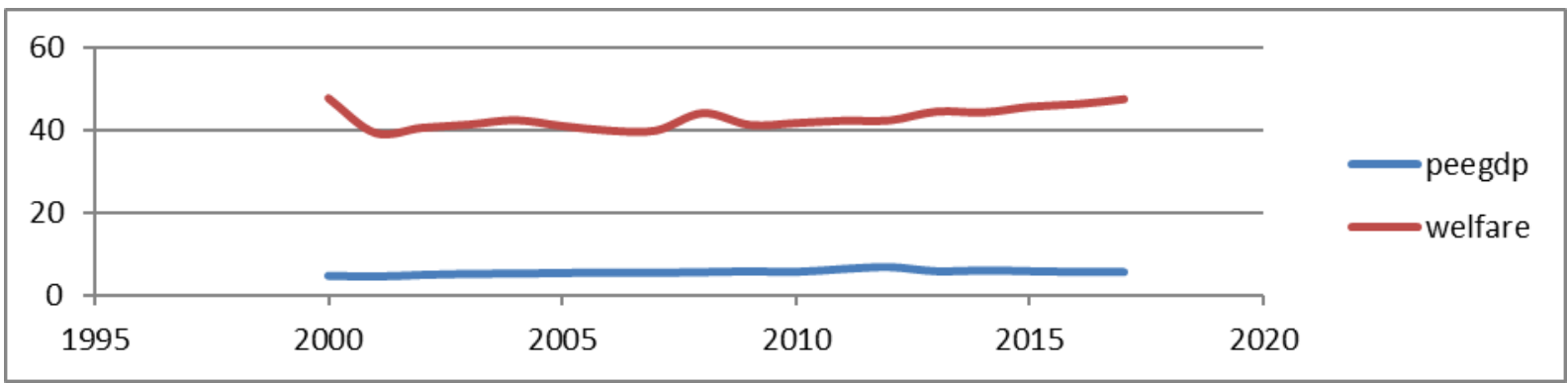

Figure 4.1: Evolution of main variables (public educational spending and economic welfare sample countries in SSA Source: Authors (2020)

Figure 4.1 shows the evolution of public educational spending from 2000-2017. We observe that the public educational spending has been near stagnant between 4.5 and 5.5 percent over the period except in 2011 when it was higher at $6.2 \%$ of the GDP. The stagnation in the value of public education expenditure could be attributed to budgetary constraints in SSA countries and the competitive needs from other sectors like health and national security. From 2000 to 2017, public educational expenditure in the sample countries averaged 5.4 percent as a percentage of GDP. This means that SSA countries are spending high on education relative to the size of their economies.

With regards to the economic welfare index, we observe from the figure that the economic welfare of the population in sample countries was generally low. From 2000-2017, economic welfare averaged only 43.11 percent. It was nearly stagnant over time though increased slightly in 2009 from $41.72 \%$ to 47.72 in 2017. Within the period, the highest value was $47.98 \%$ in 2000 and the lowest was $39.57 \%$ recorded in 2001 where it remained stable until 2007. It rose from $40.09 \%$ in 2007 to $44.33 \%$ in 2008 where it fell to $41.48 \%$ in 2009 due to the after math of the Western financial crises within this period. The steady but improving improvement in the economic welfare could have been due to the implementation of poverty reduction measures of the MDGs from 2000-2015 and the first part of the SDGs from 2015.

Whatever the situation, economic welfare remained poor within the region though variations exist across the countries. The low value of economic welfare only attest to evidence that support the fact the SSA remain one of the poorest region in the world (World Bank, 2019). Figure 4.2 shows the average level of economic welfare in all the countries in the sample. We note that though the welfare levels are generally low, there are marked variations between countries.

From the figure 4.2, we observe that in terms of economic welfare index, South Africa had the highest index of about 95 percent on average from 2000-2017. Ivory Coast was the second performer with a score of $54.96 \%$, followed by Cameroon with an average score of $52.92 \%$. Twelve countries scored below 50 in the economic welfare index. This is indicative of the fact that SSA countries have a long journey to make in terms of ameliorating the economic situations of their citizens. No doubts many studies report that SSA region remains the poorest region in the world (World Bank, 2019). In countries like Rwanda and Burundi, the economic situations of the people is yet to gain steam due to past wars, civil unrest and poor climatic conditions which have destroyed the economic bases of their economies. This explains why in our sample, these two countries scored very low on our measure of economic welfare. 


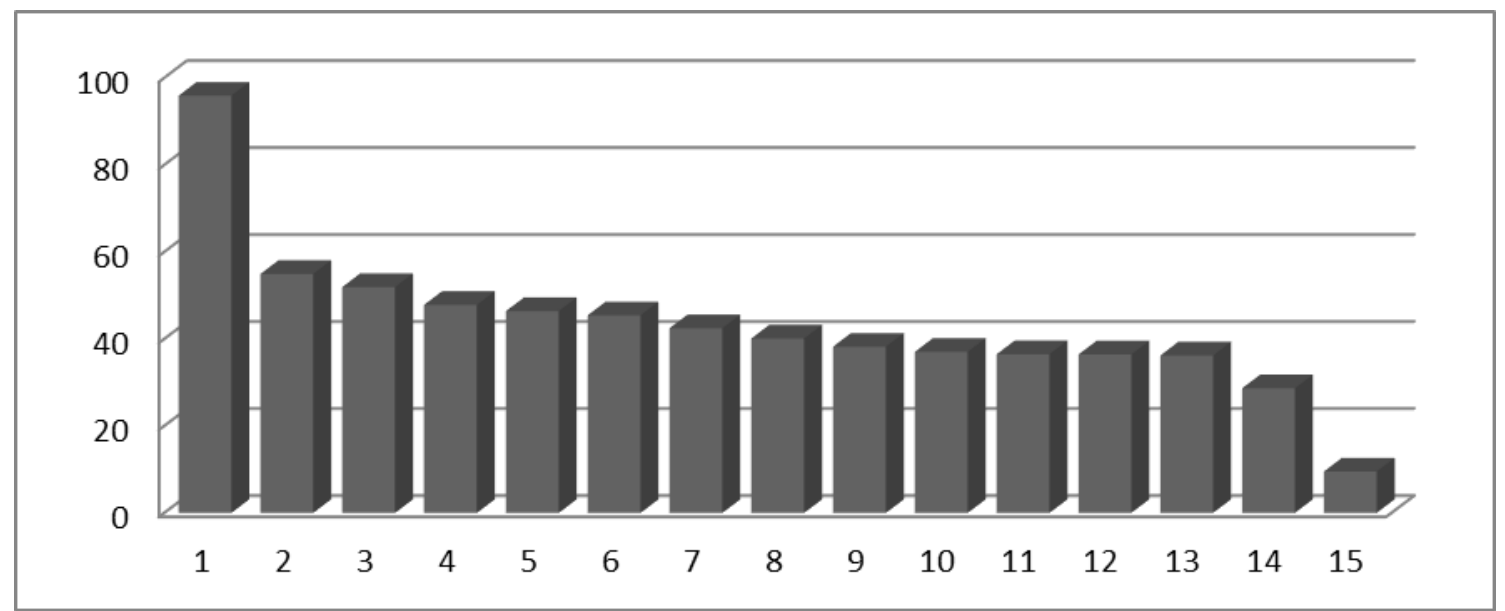

Figure 4.2: Average $^{1}$ economic welfare among countries from 2000-2017 Source: Authors (2020)

The statistical description of the variables used in our model is given in table 4.1 below.

Table 4.1: Descriptive Statistics

\begin{tabular}{|c|c|c|c|c|c|}
\hline Variable & Obs & Mean & Std. Dev. & Min & $\operatorname{Max}$ \\
\hline E- Wellbeing & 252 & .431910 & 1.000012 & .06265529 & .6993484 \\
\hline peegdp & 270 & 5.418906 & 4.941131 & 1.77992 & 37.521 \\
\hline peegdp ${ }^{2}$ & 270 & 53.6889 & 147.1958 & 3.168115 & 1407.825 \\
\hline Omega $(\Omega)$ & 270 & 3100.743 & 2002.079 & -126.5083 & 9636.104 \\
\hline acindex & 270 & 6.2210 & 1.000016 & -.9193438 & 4.135445 \\
\hline Open & 270 & 63.14279 & 26.06068 & 15 & 130.991 \\
\hline Gov & 270 & 1.6410 & 1 & -7.760221 & 2.675052 \\
\hline demo & 270 & 3.433333 & 4.77069 & -4 & 10 \\
\hline findev & 270 & -1.2909 & 1 & -.692206 & 3.749406 \\
\hline
\end{tabular}

Source: Authors, 2020

From table 4.1 we observe that the mean value of the economic welfare index is .43 while the deviation from the mean is 1.000012 . This means that on average value of economic welfare within the period was very poor. This goes to buttress the evidence from other studies which point to high level of poverty in SSA, economic inequality, environmental degradation, unemployment that characterise the economies of SSA(World Bank, 2019). The mean value of public educational spending is 5.42 while the deviation from the mean is 4.941131. The mean value of public educational spending within the average required for governments to spend in SSA. The mean value of trade openness is 63.14279 which is above the average meaning that most SSA economies are becoming more integrated to the global economy. The average value of governance is 1.6410 meaning that governance in SSA is still far from average.

\subsubsection{Correlation Analysis between the Variables Used in the Model}

Table 4.2 that follows presents the correlation coefficients which show the degree of correlation that exists between the covariates used in the model. In table 4.2, we observe that the leading diagonal has a correlation coefficient of 1 meaning that each of the variables is perfectly correlated to itself. From the table above, we observe that most of the regressors exhibit positive correlation between them. The correlation between public educational spending and the various channels such as trade openness, governance, democracy, access index and technical change are positive. This is an indication that public educational spending positively correlates with the channels and therefore would likely explain the variations in mediating variables (Avom et al. 2020). We note that there is no correlation coefficient which exceeds 0.8 meaning that there is no possibility of multicollinearity in our models. Financial development is negatively and weakly correlated to the public educational expenditure.

\footnotetext{
${ }^{1}$ Countries in order of performance from highest to the lowest as on figure 4.2 above ${ }^{1} 1$ : South Africa, $2:$ Ivory Coast, 3: Cameroon, 4: Mauritius, 5: Senegal, 6: Burkina Faso, 7: Ethiopia, 8 :Benin, 9: Mali, 10: Ghana, 11 : Niger, 12: Togo, 13: Madagascar, 14 Rwanda And 15: Burundi
} 


\begin{tabular}{|c|c|c|c|c|c|c|c|}
\hline & Peegdp & Omega & Acindex & Open & Gov & demo & Findev \\
\hline Peegdp & 1.0000 & & & & & & \\
\hline Omega & 0.0903 & 1.0000 & & & & & \\
\hline Acindex & 0.0837 & 0.0439 & 1.0000 & & & & \\
\hline Open & 0.2413 & 0.0679 & 0.5593 & 1.0000 & & & \\
\hline Gov & 0.2176 & 0.2284 & 0.3632 & 0.2471 & 1.0000 & & \\
\hline Demo & 0.2408 & 0.1884 & 0.4885 & 0.3841 & 0.5397 & 1.0000 & \\
\hline Findev & -0.0554 & 0.2170 & 0.5778 & 0.2394 & 0.6782 & 0.4458 & 1.0000 \\
\hline
\end{tabular}

Source: Authors (2020)

This means that as the economy becomes more liberalized, the size of public educational spending shrinks. This is in line with the prediction of the Rodrik (1998) hypothesis according to which public spending size falls as the economy becomes more globalised.

\subsubsection{Results of the Panel Unit Root (Stationarity Test)}

Table 4.3 in the appendix presents the outcome of the Levin-Lin and Chu unit root test (Baltagi, 2004). The results of the LLC unit root test depicts that while public educational expenditure, access index, economic welfare, governance quality and trade openness are stationary at level, democracy, financial development and technical progress are stationary at first difference. Having examined these pre-assessment results, we now present the regression results and do the interpretation of the coefficients of the variables.

\subsection{Results of the Basic Specification on the Direct Effects of Public Educational Spending on Economic Welfare in SSA Countries}

The outcome of the direct effects of educational expenditure on economic welfare are presented and analysed in this section. We begin with the results of the pooled OLS, Fixed Effects (FE) and Random Effects (RE) estimations. These are presented on the table 4.4. We begin the analysis by treating our data as a cross section and carried out pooled OLS. From observation of the pooled OLS, the coefficient of determination (RSquared is 0.933 , meaning that the quality of adjustment of our model is good. However, the pooled OLS results are not used because the strategy ignores the time dimension or component of the data. With respect to the FE and RE, we applied the Hausmann test (Baltagi, 2004) in order to select the most appropriate estimator. The results of the Haussman test are given in table in the appendix.

Table 4.4: The Results of the Direct Effects of Public Educational Expenditure on Economic Welfare in SSA countries

(1) POLS

(2) $\mathrm{FE}$

(3) RE

(4) PCSE

(5) FGLS

\begin{tabular}{|c|c|c|c|c|c|}
\hline Variables & Dependent variable: & Economic Welfare & & & \\
\hline Peegdp & $\begin{array}{c}-0.066^{* * * *} \\
(0.014)\end{array}$ & $\begin{array}{c}-0.029 * * * \\
(0.011)\end{array}$ & $\begin{array}{c}-0.032 * * * \\
(0.011)\end{array}$ & $\begin{array}{c}-0.01211 * * \\
(0.0094)\end{array}$ & $\begin{array}{l}-0.0045251 \\
(0.0055)\end{array}$ \\
\hline peegdp ${ }^{2}$ & $\begin{array}{c}0.001 * * * \\
(0.0004)\end{array}$ & $\begin{array}{c}0.0005 * * * \\
(0.0002)\end{array}$ & $\begin{array}{c}0.0006^{* * * *} \\
(0.0002)\end{array}$ & $\begin{array}{c}0.0036^{* *} \\
(0.0012)\end{array}$ & $\begin{array}{l}0.0009 \\
(0.0001)\end{array}$ \\
\hline Omega & $\begin{array}{l}-0.0209 \\
(0.0211)\end{array}$ & $\begin{array}{c}-0.0170 \\
(0.0138)\end{array}$ & $\begin{array}{l}-0.0152 \\
(0.0143)\end{array}$ & $\begin{array}{l}-0.0012 \\
(0.0056)\end{array}$ & $\begin{array}{l}-0.0009 \\
(0.0058)\end{array}$ \\
\hline Acindex & $\begin{array}{c}0.517 * * * * \\
(0.0306)\end{array}$ & $\begin{array}{c}0.317 * * * \\
(0.0184)\end{array}$ & $\begin{array}{c}0.321 * * * \\
(0.0189)\end{array}$ & $\begin{array}{c}0.4162 * * * \\
(0.0624)\end{array}$ & $\begin{array}{l}0.2907 * * * \\
(0.0294)\end{array}$ \\
\hline Open & $\begin{array}{c}0.006 * * * \\
(0.001)\end{array}$ & $\begin{array}{c}-0.003 * * * \\
(0.001)\end{array}$ & $\begin{array}{c}-0.003 * * * \\
(0.001)\end{array}$ & $\begin{array}{l}0.0016^{*} \\
(0.0008)\end{array}$ & $\begin{array}{l}0.0002 \\
(0.0004)\end{array}$ \\
\hline Gov & $\begin{array}{c}0.266 * * * \\
(0.027)\end{array}$ & $\begin{array}{l}0.123 * * * \\
(0.0201)\end{array}$ & $\begin{array}{c}0.135^{* * * *} \\
(0.0207)\end{array}$ & $\begin{array}{c}0.1441 * * * \\
(0.0265)\end{array}$ & $\begin{array}{l}0.0672 * * * \\
(0.0156)\end{array}$ \\
\hline Demo & $\begin{array}{l}-0.002 \\
(0.004)\end{array}$ & $\begin{array}{c}0.004 \\
(0.004)\end{array}$ & $\begin{array}{c}0.001 \\
(0.004)\end{array}$ & $\begin{array}{c}0.0023^{* *} \\
(0.0023)\end{array}$ & $\begin{array}{l}0.0028 \\
(0.0019)\end{array}$ \\
\hline Findev & $\begin{array}{c}0.208 * * * \\
(0.028)\end{array}$ & $\begin{array}{c}0.216^{* * * *} \\
(0.040)\end{array}$ & $\begin{array}{c}0.238 * * * \\
(0.039)\end{array}$ & $\begin{array}{c}0.2720 * * * \\
(0.0410)\end{array}$ & $\begin{array}{l}0.2463 * * * \\
(0.0281)\end{array}$ \\
\hline
\end{tabular}




\begin{tabular}{|c|c|c|c|c|c|}
\hline Cons. & $\begin{array}{c}0.0680 \\
(0.170)\end{array}$ & $\begin{array}{c}0.470 * * * \\
(0.121)\end{array}$ & $\begin{array}{c}0.403 * * * \\
(0.150)\end{array}$ & $\begin{array}{l}-0.0662 \\
(0.0765)\end{array}$ & $\begin{array}{l}-0.1528 * * \\
(0.0604)\end{array}$ \\
\hline \multirow{4}{*}{$\begin{array}{l}\text { Waldchi2 8) } \\
\text { p-value } \\
\text { F-chi2 }\end{array}$} & & & & 279.39 & 412.73 \\
\hline & & & & 0.0000 & 0.0000 \\
\hline & & & & & \\
\hline & 420.9 & 0.789 & 875.2 & & \\
\hline R-sq. & 0.933 & 0.789 & - & 0.7398 & - \\
\hline No. obs. & 252 & 252 & 252 & 252 & 252 \\
\hline
\end{tabular}

From the results, we observe that the p-value is less than the five percent threshold. In this case, we reject the null hypothesis and conclude that the RE model is the most appropriate.

We cannot use the outcomes of the FE estimator unless the results are void of heteroskedasticity and autocorrelation. This is because according Avom et al (2020) and Keufack et al. (2020), in the presence of autocorrelation and heteroskedasticity of errors, the estimates of the FE estimator are bias and inconsistent. We have to further investigate the presence or absence of heteroskedasticity and autocorrelation. The results are given on tables $4.12 \mathrm{a}$ and $4.12 \mathrm{~b}$ in the appendix. From the outcome of the tests for autocorrelation and heteroskedasticity, we conclude that there is autocorrelation and heteroskedasticity. To this effect, the Pooled OLS and FE estimates are bias, unreliable and inconsistent. On this note, we used the PCSE estimator to estimate the parameters of the model. This is because in the presence of autocorrelation and heteroskedasticity, the PCSE estimator gives consistent and reliable estimates of the parameters (Avom et al. 2020).

\subsection{Results of the Panel Corrected Standard error Estimator on the direct Effects of Educational Expenditure on Economic Welfare in SSA Countries}

The results of the PCSE estimator are presented by regression 4 on table 4.4. The p-value of the Wald test is 0.0000 meaning that our model is globally significant and is estimated with little errors. The R- square of the model is 0.7398 meaning that our explanatory variables explain up to $73.98 \%$ of the variations in economic welfare. We begin by interpreting the coefficient of the variables in the model and relate them to other empirical works.

The result reveals that public educational spending has negative and significant effects on economic well being is SSA. All things being equal, one unit increase in the size of public educational expenditure leads to a reduction in economic well-being by -0.01211 point. Thus is in line with the expected sign. The negative effect of public educational expenditure and well-being could be due to the low and inefficient use of public expenditure in most countries in SSA (Koku, 2015, Fonchamnyo and Sama, 2014). The result is consistent with the findings of Diyoke and Demirbas (2018) based on lower and middle income countries in SSA. Equally, Bexheti and Mustafi (2015) found out that public educational expenditure negatively affect economic growth in Macedonia. However, this is contrary to the result of Urhie (2014) in Nigeria according to which current educational spending has positive and significant effects on per capita income in Nigeria.

Secondly, our results depict that additional funding for education is vital for economic welfare. The quadratic term shows that more spending for education has significant positive effects on economic welfare in SSA. All things being equal, doubling public educational spending leads to a 0.00364 point increase in economic welfare in SSA. This means that public spending size matter for economic welfare in SSA. This is in support of other studies that had that money matter for educational outcomes (Baker, 2012).

Thirdly, we observe that the quantity of education or human capital matters much for economic welfare in SSA (Lucas, 1988). This is because educational access has positive and significant effects on economic welfare in SSA. The result is in line with the expected sign. A one unit rise in access to education leads to a 0.4162 point increase in economic welfare in SSA. This is surely because in SSA, there is need to reduce the level of underscolarisation and improve on rise literacy via enrolment before raising the quality of schooling. Increasing literacy via enrolment has greater payoffs for developing SSA countries. This result is also in line with that of Khattak (2012 in Pakistan according to whom an improvement in education has positive effects on economic growth. Akinola and Bokana (2017) whose study was based on SSA concluded that the levels of schooling positively and significantly affect per capital income in SSA.

The level of technological progress which captures quality education has positive effects on economic welfare but the effects are not significant. This means that the educational systems in SSA do not inculcate adequate cognitive skills in the learners. This is surely real given the less attention that was paid to technical and vocational education in most SSA in the past. This suggests that the quality of education does not matter much for welfare of the population in SSA. This is at variant with the studies of Hanusheck and Woessmann (2007) and Hanushek and Kimko(2000) who concluded that educational quality measured by cognitive skills have a greater bearing on economic growth.

Trade openness has positive and significant effect on economic welfare in SSA. The expected sign is respected. A one unit increase in trade openness leads to a 0.0016 point increase in economic welfare in SSA. 
This is obvious because trade openness allows for market expansion, exposure to variety of consumer goods and services, higher quality goods and services due to competition, improvement in technology which all go to ameliorate economic welfare. The findings are consistent with that of Hanushek and Woessman (2008). This result is also in line with that of Hawkes and Wargur (2017) based on developing countries and Trabelis (2017) based on cross country studies. All the studies concluded on the affirmative on the effects of trade on welfare.

Institutional quality or governance captured by control of corruption and government effectiveness has positive and significant effects on economic welfare. The outcome is in line with the expected sign. A one unit improvement is governance quality leads to an increase in economic welfare by 0.1441 point. The result is consistent for all the specifications. The outcome is due to the positive role of institutions in promoting both private domestic and foreign direct investment. It is also due to the positive role of governance on improving the efficiency of public spending (Kagundu, 2006). This is consistent with the findings of Burkiewicz and Yanikkaya (2011) who held that governance has positive effects on the welfare of the people in SSA, Latin America and East Asia. This is also consistent with the findings of Hanushek and Woessmann (2008), Hanushek and Kimko (2000). Kagundu (2006) held that the quality of governance has positive and significant effects on per capital income.

Democracy has positive and significant effects on economic welfare in SSA. The result is in line with the priory expectations. All things being equal, a one unit increase in democracy leads to a 0.0023 point improvement in economic welfare in SSA. This is because democracy improves on civil liberty and is positively related with the quality of institutions. A more democratic country attracts foreign direct investment which improves economic growth.

Financial development or deepening has positive and significant effects on economic welfare in SSA. This is in line with the expected sign. A one unit improvement in financial development leads to a 0.2720 point increase in economic welfare in SSA. This is in line with theoretical and empirical predictions of McKinnon \& Shaw (1973). The result is consistent with that of Akpansung and Babalola (2011) who held that bank credit to the private sector enhances economic growth in Nigeria.

In our analysis, we adopted the FGLS estimator for the robustness checks of the direct effects of educational expenditure on economic welfare in SSA. Just like the PCSE estimator, this estimator yields unbiased and consistent parameters estimates. We observe that though some key variables like public educational expenditure, the square of public educational expenditure, trade openness and democracy have lost their significance, they are still consistent in terms of the direction of their signs. At the same time, access to education a measure of human capital, governance and financial development are consistent in their signs and levels of significance. This makes our findings robust.

\subsection{Evaluating the Importance and Significance of the Transmission Channels}

Our second specific objective is to evaluate the indirect effects of public educational spending on economic welfare in SSA. This is done by evaluating the various channels via which educational expenditure impact on economic welfare (Urhie, 2014, Hanushek and Woessmann, 2008). Our results are based on the causal mediation analysis and the use of the traditional interactive approach for robustness checks.

Our results in table 4.5 show that public educational spending affects all the 5 channels and therefore account for part of the variations in the channels of effects. The logic is that if the public educational expenditure impact of the channels and the channels affect economic welfare, the public educational expenditure indirectly affects economic welfare (Fabrizio, 2018). Table 4.5 presents the results of the effects of public educational expenditure on the channels.

Table 4.5: Results from the Structural Equation Models (SEM): Testing the Effects of public educational expenditure on different channels

\begin{tabular}{llllll}
\hline Channels & Omega & Acindex & Gov & Demo & open \\
\hline Indep.Var(Peegdp) & $0.025^{* * *}$ & $0.0155^{* * *}$ & $0.0438^{* * *}$ & $0.224^{* * *}$ & $\left(.189^{* * *}\right.$ \\
& $(0.006)$ & $(0.0075)$ & $(0.005)$ & $-026)$ & $(0.188)$ \\
\hline Constant & $7.670^{* * *}$ & -0.058 & $-0.232^{* * *}$ & $-0.32 * * *$ & $(0.079)$ \\
\hline Observations & $(0.079)$ & $(0.083)$ & $(0.079)$ & $252.33^{* * *}$ & $(2.073)$ \\
\hline
\end{tabular}

Boostrap Standard errors in parentheses, $* * * \mathrm{p}<0.01, * * \mathrm{p}<0.05, * \mathrm{p}<0.1$

Source: Authors (2020)

From the results in table 4.5, "Ceteris Paribus", an increase in public educational spending boosts educational access, technological progress, trade openness, governance quality and democracy. A one point increase in public educational expenditure stimulates technological progress, school access, governance quality, democracy and trade openness by $0.025,0.0155,0.0428,0.224$ and 1.189 points respectively. This is in line with the study of Kagundu (2006) who concluded that educational spending predicts governance in Africa. Urhie (2014) concluded in his study in Nigeria that Public educational expenditure affects economic growth via human capital. This means that educational expenditure first ameliorate human capital before affecting welfare (Lucas 
(1988) and Fabrizio (2018)). Since public educational expenditure explains part of the variations in the transmission channels, we can then compute the indirect effects of public educational expenditure on economic welfare in SSA (Avom et al. 2020). Table 4.6 shows the results.

Table 4.6: The Indirect Effects of Public Educational Expenditure on Economic Welfare via various channels

\begin{tabular}{|c|c|c|c|c|c|}
\hline & omega & acindex & gov & demo & open \\
\hline Indirect effect & $\begin{array}{l}-0.001 \\
(0.001)\end{array}$ & $\begin{array}{l}0.008 * * \\
(0.004)\end{array}$ & $\begin{array}{l}0.012 * * * \\
(0.002)\end{array}$ & $\begin{array}{l}0.001 \text { *** } \\
(0.001)\end{array}$ & $\begin{array}{l}0.028^{* * * *} \\
(0.004)\end{array}$ \\
\hline
\end{tabular}

Boostrap Standard errors in parentheses, $* * * \mathrm{p}<0.01, * * \mathrm{p}<0.05, * \mathrm{p}<0.1$

Source: Authors (2020)

Our result from table 4.6 shows that 4 out the five channels have positvely mediated the negative effects of public educational spending on economic welfare in SSA. Over the period given, government spending on educational has indirectly improved welfare via educational access, governance quality, democracy and trade openness while its indirect effect via technical progress is negative but statistically insignificant. As part of our analysis, we further estimate the contribution of each channel to the total effect of public Educational spending on economic welfare in SSA. We conclude following results from table 4.6 that about $27.9 \%, 42.0 \%, 1.4 \%$ and $35.0 \%$ of the total negative of public educational expenditure on economic welfare is mediated by school access, governance quality, democracy and trade openness respectively.

To end up, we derived the total effect of public educational spending on economic welfare in SSA. The results are presented in table 4.7. On the basis of the results of table 4.7 , we conclude that a $1 \%$ increase in public educational spending leads to the 0.040 point of public economic welfare in SSA. Although the coefficient changes, the sign and level of significance are highly consistent with the result obtained in the PCSE estimations.

Table 4.7: The Total Effect of Public Educational Expenditure on Economic Welfare

\begin{tabular}{|c|c|}
\hline \multicolumn{2}{|c|}{ Dependent variable: Economic Welfare } \\
\hline Variables & Coefficients \\
\hline Solow residual $(\log )$ & $\begin{array}{l}-0.021 \\
(0.024)\end{array}$ \\
\hline Access index (schooling) & $\begin{array}{l}0.517 * * * \\
(0.041\end{array}$ \\
\hline Governance & $\begin{array}{l}0.266^{* * * *} \\
(0.029)\end{array}$ \\
\hline Democracy & $\begin{array}{l}-0.002 \\
(0.004)\end{array}$ \\
\hline Trade openness & $\begin{array}{l}0.006 * * * \\
(0.001)\end{array}$ \\
\hline Educational Exp. (\% of GDP) & $\begin{array}{l}0.040 * * * \\
(0.033)\end{array}$ \\
\hline Educational Exp. Squared & $\begin{array}{l}0.001 \\
(0.001)\end{array}$ \\
\hline Financial development index & $\begin{array}{l}0.207 * * * \\
(0.029)\end{array}$ \\
\hline Observations & 252 \\
\hline Number of groups & 15 \\
\hline
\end{tabular}

\subsection{Conclusion}

In this paper we investigated how public educational expenditure affects the economic welfare of the people in 15 countries in SSA over 2000-2017. Specifically, we investigated the direct effects of public educational spending on economic welfare in SSA countries and the roles of educational access, technical change, trade openness, governance and democracy in mediating these effects. The results of our static panel reveal that while public educational expenditure has negative and significant effects on the economic welfare of the people in SSA, on the other hand, the square of pubic educational expenditure, access to education, governance quality, trade openness, democracy and financial development have positive and significant effects on economic welfare in SSA. This goes to confirm our first hypothesis. To complement our analysis, we resorted 
the investigating the mediating roles of trade openness, educational access, technical change, democracy and governance on the effects of public educational expenditure on economic welfare in SSA countries. Our results revealed that while trade openness, democracy, economic governance and educational access greatly ameliorated the negative effects of public educational expenditure on economic welfare, the mediating effects of technical progress are rather ambiguous and inconsistent. Hence, public educational expenditure does not only directly affect economic welfare but it also does so indirectly via the above channels. The results do not confirm the second hypothesis because technical change negatively but insignificantly increased the negative effects of public educational expenditure on economic welfare.

\subsection{Policy Implications}

From a policy perspective, the following measures could be adopted in order to ameliorate the effects of public educational expenditure on economic welfare in SSA. Firstly, governments need to consistently increase the sizes of their budgetary allocations to the educational sector even above the UNESCO recommended target. Secondly, there is need to improve on governance, educational access and the quality of education. Lastly, the gradual economic liberalization of the economies is highly welcome.

\section{References}

Abubakar, A. B. (2016). Dynamic effects of fiscal policy on output and unemployment in Nigeria: an econometric investigation. CBN Journal of Applied Statistics, 7(2), 101-122.

AfDB (2020). Africa on Focus. Figures of the Week. Public spending on education in Africa. African economic outlook. African growth initiative. African Development Bank, Abijan.

Akinola, G. W., \& Bokana, K. G. (2017). Human Capital, Higher Education Enrolment and Economic Growth in the SSA Countries (Panel Model Approach). Journal of Economics and Behavioral Studies, 9(6), 215-226.

Armey, R. K. (1995). The freedom revolution: the new republican house majority leader tells why big government failed, why freedom works, and how we will rebuild America. Regnery Publishing.

Akpansung, A. O., \& Babalola, S. J. (2011). Banking sector credit and economic growth in Nigeria: An empirical investigation. CBN Journal of Applied Statistics, 2(2), 51-62.

Appiah, E. N. (2017). The Effect of education expenditure on per capita gdp in developing countries. International Journal of Economics and Finance, 9(10), 136-144.

Abbubakar M S H, Iram S Asma S and Riswan M M (2016); The impact of governance and institutionson education and poverty alleviation.A panelstudy in SAARC economies. MPRA paper number 71248, scientific international journal;28 (8):1431-1435.

Avom, D., Nkengfack, H., Fotio, H. K., \& Totouom, A. (2020). ICT and environmental quality in Sub-Saharan Africa: Effects and transmission channels. Technological Forecasting and Social Change, 155, 120028.

Babalola, S. J., \& Aminu, U. (2011). Fiscal policy and economic growth relationship in Nigeria. International Journal of Business and Social Science, 2(17): 123- 147

Baker, B. D. (2012). Does money matter in education?. Albert Shanker Institute.

Barro, R. J. (1989). A Cross-Country Study of Growth, Saving and Government. NBER Working Paper No. 2855.

Barro, R. J. (1989). The Ricardian approach to budget deficits. Journal of Economic perspectives, 3(2): 37-54.

Barro, R. J. (1990). Government Spending in a Simple Model of Endogenous Growth. The Journal of Political Economy, 98 (5): 103-125.

Barro, R. J. (1991). Economic growth in a cross section of countries. The quarterly journal of economics, 106(2): 407-443.

Barro, R. J., \& Martin, S. I. X.(2004). Economic growth, . Journal of Macroeconomics, (18) 552. 
Baltagi, B. H. (2004). 04.1. 1. A Hausman Test Based on the Difference between Fixed Effects Two-Stage Least Squares and Error Components Two-Stage Least Squares. Econometric Theory, 20(1), 223-224.

Becker, G. S., \& Chiswick, B. R. (1966). Education and the Distribution of Earnings. The American Economic Review, 56(1/2): 358-369..

Bexheti, A., \& Mustafi, B. (2015). Impact of public funding of education on economic growth in Macedonia (No. 98). BERG Working Paper Series.

Bils, M., \& Klenow, P. J. (2000). Does Education Cause Growth. American Economic Review, 90(5): 11601183.

Butkiewicz, J. L., \& Yanikkaya, H. (2011). Institutions and the impact of government spending on growth. Journal of Applied Economics, 14(2) : 319-341.

Brempong, K. (2010). Education and economic development in Africa. African development review, 23(2): 219236.

Blankneau, W. F., \& Simpson, N. B. (2004). Public education expenditures and growth. Journal of development economics, 73(2): 583-605.

Çakerri, L., Petanaj, M., \& Muharremi, O. (2014). The effect of government expenditures on economic growth. The case of Albania. European Journal of Social Science Education and Research, 1(2): 242-253.

Chelli-Chentouf, N., Meddah, A. T. T., Mullié, C., Aoues, A., \& Meddah, B. (2012). In vitro and in vivo antimicrobial activity of Algerian Hoggar Salvadora persica L. extracts against microbial strains from children's oral cavity. Journal of ethnopharmacology, 144(1): 57-66.

Churchill S A, Ugur M and Yew, S.L (2016). Government Educational Expenditures And Economic Growth. A Meta Analsysis. The business economics journal of macro economics, 17 (2): 425-490.

Daly, H. E., Cobb Jr, J. B., \& Cobb, J. B. (1994). For the common good: Redirecting the economy toward community, the environment, and a sustainable future (No. 73). Beacon Press.

Deskins, J., Hill B and Ullrich L (2019) . Educational Spending And State Economic Growth. Are All Dollars Created Equal?. SAGE journal, economic development quarterly;8(5): 123-145

Devarajan, S., Swaroop, V., \& Zou, H. F. (1996). The composition of public expenditure and economic growth. Journal of monetary economics, 37(2): 313-344.

Dhruv, G (2020). Africa Focus: FIGURES OF THE WEEK. Public spending on education in Africa. African economic outlook. African growth initiative. African Development Bank, Abijan.

Ditimi, A., Babalalo, J. A., Philip, N., \& Adebayo, A. T. (2011). Components of Government Spending and Economic Growth in Nigeria: An Error Correction Modeling. Journal of Economics and Sustainable Development, 2(4): 219-237

Diyoke, K. O., Yusuf, A., \& Demirbas, E. (2017). Government Expenditure and Economic Growth in Lower Middle Income Countries in Sub-Saharan Africa: An Empirical Investigation. Asian Journal of Economics, Business and Accounting, 1-11.

Eggoh, J., Houeninvo, H., \& Sossou, G. A. (2015). Education, health and economic growth in African countries. Journal of Economic Development, 40(1): 93-115

Fabrizio Carmignami (2016). Does government spending on education promote economic growth? Publication , Griffith University. The Conversaion.Com.Autralia Research Council.

Facchini F. \& Melki M. (2011). Optimal Government Size and Economic Growth in France (1871-2008): En Explanation by the State and Market Failures, CES Working Papers, ISSN: 1955-611X, Paris: 1-38. 
Feyzioglu T, Swaroop V and Zhu M (1996). Foreign aid impact on public spending

Fonchamnyo, D. C., \& Sama, M. C. (2014). Determinants of public spending efficiency in education and health: evidence from selected CEMAC countries. Journal of Economics and Finance, 40(1): 199-210.

Fonkeng, G. \& Ntembe, A. (2009). Higher education and economic development in Africa: The case of Cameroon, Educational Research and Review, 4 (5): 231-246

Gisore, N., Kiprop, S., Kalio, A., Ochieng, J., \& Kibet, L. (2014). Effect of government expenditure on economic growth in East Africa: A disaggregated model. European journal of business and social sciences, 3(8): 289-304.

Grossman, P. J. (1988). Government and economic growth: A non-linear relationship. Public Choice, 56(2) : 193-200.

Hanushek, E. A., \& Kimko, D. D. (2000). Schooling, labor-force quality, and the growth of nations. American economic review, 90(5): 1184-1208.

Hanushek, E. A., \& Woessmann, L. (2008). The role of cognitive skills in economic development. Journal of economic literature, 46(3): 607-68.

Hanushek, E. A., \& Woessmann, L. (2012). Do better schools lead to more growth? Cognitive skills, economic outcomes, and causation. Journal of economic growth, 17(4): 267-321.

Hanushek, E. A., \& Woessmann, L. (2015). The knowledge capital of nations: Education and the economics of growth. MIT press.

Hanushek, Eric A., and Ludger Wössmann (2007). The role of education quality in economic growth. Policy Research Working Paper, No. 4122. Washington, D.C.: World Bank.

Ibok, O. W., \& Bassey, N. E. (2014). Wagner's law revisited: The case of Nigerian agricultural sector (19612012). International Journal of Food and Agricultural Economics (IJFAEC), 2(1128-2016-92045): 19-32.

Khattak, N. U. R. (2012). The contribution of education to economic growth: Evidence from Pakistan. Pakistan Journal of Economic Development, 6(4):20-44

Keynes, J. M. (1936). The general theory of interest, employment and money. UK

Kenfack, G.F., Ningaye, P \& Kuipou, T. C (2020).Global Value Chain Participation and Current Account Balances in Landlocked: African Countries.Journal of economics and trade: 26 (2): 1-14

Kimaro, E. L., Keong, C. C., \& Sea, L. L. (2017). Government expenditure, efficiency and economic growth: a panel analysis of Sub Saharan African low income countries. African Journal of Economic Review, 5(2): 34-54.

Koku, A. I. (2015). Efficiency of Government Expenditure in the ECOWAS Sub-Region (Doctoral dissertation, University of Ghana. Ghana

Kouton, J. (2018). Education expenditure and economic growth: Some empirical evidence from Côte d'Ivoire.

Kohl D (2015). Effects of Education on Income And employment: applied journal; 12 (7): 123-145

Kushwaha, M and Tiwari R (2019). An empirical investigation of public educational expenditure and economic growth in Gujarati: available at SSRN: http/:2457074

Kuznets, S. (1934). National Income, 1929-1932. In National Income, 1929-1932 (pp. 1-12). NBER.

Maitra, B., \& Mukhopadhyay, C. K. (2012). Public spending on education, health care and economic growth in selected countries of Asia and the Pacific. Asian pacific development journal; 19 (2): 123-155.

Mankiw, N. G., Romer, D., \& Weil, D. N. (1992). A contribution to the empirics of economic growth. The quarterly journal of economics, 107(2), 407-135

McKinnon, R., \& Shaw, E. (1973). Financial deepening in economic development. Washington, Brookings Institution. 
Mincer, J. (1974). Progress in Human Capital Analysis of the distribution of earnings (No. w0053). National Bureau of Economic Research. No. 2.

Mohamed J , Mohamed B and Asongu S (2015). Institutions, education and economic growth. MPRA paper no. 71785. AGDI WP/15/059. African governance and development institute, Yaounde, Cameroon.

Musila, J. W., \& Belassi, W. (2004). The impact of education expenditures on economic growth in Uganda: evidence from time series data. The Journal of Developing Areas, 3 (2):123-133.

Mussagy, I. H., \& Babatunde, M. A. (2015). Government spending on education and Economic growth in mozambique: a cointegration approach. Revista Electrónica de Investigação e Desenvolvimento, (5).

Musharrat (2011). Does institutional quality matter on link between public spending, poverty and inequality. Review of economics and management. 3(2): 96- 115

Mitchell D (2005). The impact of government spending on economic growth. Report budget. Heritage foundation, USA.

Ndoye, A. A. J. (2013). Measuring returns to Education and decomposition of rural-urban Inequality: Evidence from Senegal. Working Paper: International Household Survey Network.

Neycheva, M. (2010). Does public expenditure on education matter for growth in Europe? A comparison between old EU member states and post-communist economies. Post-communist economies, 22(2): 141-164.

Nicholas, F R (1999). The British relative economic performance. 1870-1999. Institution of economic affairs, 2002

Nordhaus, W. D., \& Tobin, J. (1972). Economic growth (Vol. 5). National Bureau of Economic Res.

Pigou, A. (1932). C .(1920) The Economics of Welfare.

Ram, R. (1986). Government size and economic growth: A new framework and some evidence from crosssection and time-series data. American Economic Review 76 (1): 191-203.

Rahn, R. \& Fox, H. (1996). What is the Optimum Size of Government, Vernon K. Kriebe Foundation.

Rajkumar, A. S., \& Swaroop, V. (2008). Public spending and outcomes: Does governance matter?. Journal of development economics, 86(1): 96-111.

Rebelo, S. (1991). Long-run policy analysis and long-run growth. Journal of political Economy, 99(3): 500-521.

Riedl, B. (2008). Why government spending does not stimulate economic growth. Heritage Foundation.

Robert, L. (1988). On the mechanics of economic development. Journal of monetary economics.

Romer, P. M. (1986). Increasing returns and long-run growth. Journal of political economy, 94(5): 1002-1037.

Romer, P. M. (1990). Endogenous technological change. Journal of political Economy, 98(5, Part 2): S71-S102.

Rodrik, D. (1998). Why do more open economies have bigger governments?. Journal of political economy, 106(5): 997-1032.

Scully, G. (1994), What is the Optimal Size of Government? Policy Report, No: 188, National Centre for Policy Analysis, Dallas.

Scully, G. (2008). Optimal Taxation, Economic Growth and Income Inequality in the United States. National Center for Policy Analysis, Policy Report No. 316.

Siddiki J U (2010). The Ricradian Equivalent Hypothesis : Evidence From Bangladesh. Applied Economics. Taylor and Francis (Routledge:42(11):1419-1435.

Solow, R. M. (1956). A contribution to the theory of economic growth. The quarterly journal of economics, 70(1): 65-94. 
Stiglitz, J. E., Sen, A., \& Fitoussi, J. P. (2010). Mismeasuring our lives: Why GDP doesn't add up. The New Press.

Stock, J. H., \& Watson, M. W. (2008). Heteroskedasticity-robust standard errors for fixed effects panels

Szirmai, A. (2015). Socio-economic development. Cambridge University Press.

Tanzi, V., \& Schuknecht, L. (2000). Public spending in the 20th century: A global perspective. Cambridge University Press.

Torruam, J. T., Chiawa, M. A., \& Abur, C. C. (2014). Cointegration analysis of public expenditure on tertiary education and economic growth in Nigeria. CBN Journal of Applied Statistics, 5(2): 137-146.

Trabelsi, S (2018): Public educational expenditures and economic growth.the governance threshold effects. Journal f economic development, 43(1): 101-124/

Jambo N. (2017). The impact of government expenditure on agricultural growth:the case of Zambia, Tanzania, South Africa and Malawi.Masters dissertation.

Jumbo U. E. and Atabukum F.D (2020). Perceptions of the effects of Community Microfinance on the economic welfare of households: evidence from Soliarairy Funds of development of Rural Mezam in Cameroon; Review Of Economics And Management Sciences, 1(1): 65-87.

United Nations Educational, Scientific and Cultural Organization (UNESCO). (2018). Global education monitoring report 2019: migration, displacement and education: building bridges, not walls.

UNESCO (2011): financing education in sub Saharan Africa. Meeting the challenges of expansion, equity and quality. UNESCO and Pole de Dakar.

Urhie, E. S. (2014). Public education expenditure and economic growth in Nigeria: a disaggregated approach. Journal of Empirical Economics, 3(6): 370-382.

Uzawa, H. (1965). Optimum technical change in an aggregative model of economic growth. International economic review, 6(1): 18-31.

Van de Ven, P. (2018). Measuring Economic Welfare: A Practical Agenda for the Present and the Future1 (Draft Version).

Wagner, A. (1883). Three extracts on public finance. In Classics in the Theory of Public Finance, R.A.

Woodridge, J. M. (2002). Econometric analysis of cross sectional data and panel data. Cambridge and.anel data regression. Econometrica, 76(1): 155-174

World Bank (2019). World development indicators: World Bank, Washington DC, USA

World Bank (2018). World development indicators: World Bank, Washington DC, USA

\section{Appendix}

Table 4.3: Results of LLC Unit Root Test

\begin{tabular}{lll}
\hline Variable & F-Statistics and P-value & Level of integration \\
\hline peegdp & $-1.4558^{*}$ & $1_{0}$ \\
acindex & $-2.4105^{* * *}$ & $\mathrm{I}_{0}$ \\
Ew & $-3.2765^{* * *}$ & $\mathrm{I}_{0}$ \\
Gov & $-8.6638^{* * *}$ & $\mathrm{I}_{0}$ \\
Findev & $-8.2026^{* * *}$ & $\mathrm{I}_{1}$ \\
$\Omega$ & $-3.8776^{* * *}$ & $\mathrm{I}_{1}$ \\
Demo & $-1.9363^{* *}$ & $\mathrm{I}_{1}$ \\
open & $-4.7401^{* * *}$ & $\mathrm{I}_{0}$ \\
\hline
\end{tabular}

$*, * *, * * *$ are the significance levels at 10,5 and $1 \%$ respectively

Source: Authors (2020) 
Table 4.11: The Results of the Haussmann Test

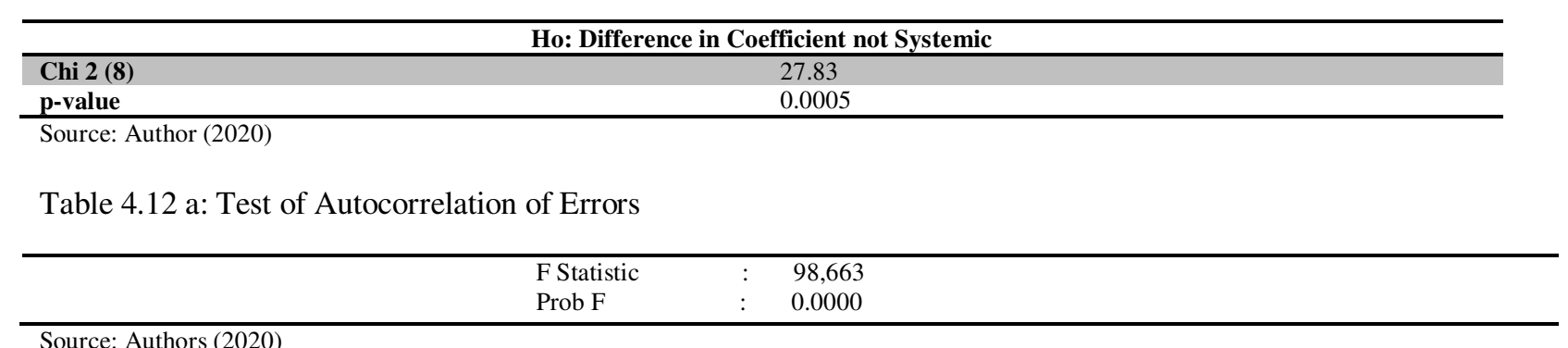

Source: Authors (2020)

Table 4.12b: GroupWise test for Heteroskedasticity

$\begin{array}{lll}\text { Chi } 2 & : & 18543.88 \\ \text { Prob } & : & 0.0000\end{array}$

Source : Authors (2020)

\section{List of countries used in the study}

Cameroon, Ethiopia, Ghana, Senegal, Rwanda, Mauritius, Mali, Madagascar, South Africa, Burundi, Niger, Togo, Benin, Burkina Fasso and Ivory Coast 